\title{
Implementation Cooperative Learning Type STAD Assisted Edmodo in Improving Students' Critical Thinking Skills
}

\author{
Muhamad Epi Rusdin ${ }^{1 *}$, Widodo ${ }^{2}$, and Guntur Maruto ${ }^{3}$ \\ ${ }^{1}$ Department of Physics Education, IKIP Muhammadiyah Maumere \\ J1. Jendral sudirman, Sikka, Nusa Tenggara Timur, Indonesia \\ ${ }^{2}$ Master Program of Physics Education, Universitas Ahmad Dahlan \\ Jl. Pramuka No. 42, Yogyakarta, Daerah Istimewa Yogyakarta, Indonesia \\ ${ }^{3}$ Department of Physics Education, Universitas Gadjah Mada \\ Bulaksumur, Sleman, Daerah Istimewa Yogyakarta, Indonesia \\ *Email: Cepi.rusdin@gmail.com
}

\begin{tabular}{ll}
\hline \multicolumn{1}{c}{ Article Info } & ABSTRACT \\
\hline $\begin{array}{l}\text { Article History } \\
\text { Received Feb 17, 2020 }\end{array}$ & The STAD cooperative learning model can support active, independent and \\
Revised May 16, 2020 & responsible learning for students. The application of this model is expected to \\
Accepted June 23, 2020 & the improvement of students' critical thinking skills using Edmodo-assisted learning \\
\hline & models. Edmodo was modified to become a teacher tool to expand learning at home. \\
Keywords: & This research is an experimental study using a pretest-posttest control group design \\
Cooperative Learning & involving 39 students of class VIII MTs At-Taqwa Beru, Sikka, East Nusa Tenggara. \\
Critical Thinking Skill & Based on the results of the study it was found that the Edmodo-assisted STAD type \\
E-learning & cooperative learning model can improve students' critical thinking skills. \\
Edmodo & \\
LMS & \\
STAD & \\
\hline To cite this article: & \\
M. E. Rusdin, Widodo, and G. Maruto, "Implementation Cooperative Learning Type STAD Assisted Edmodo in \\
Improving Students' Critical Thinking Skills," Indones. Rev. Phys., vol. 3, no. 1, pp. 30-34, 2020. \\
\hline
\end{tabular}

\section{Introduction}

Learning will be saying to be successful and qualified if the majority of students actively involved, both physically, mentally, and socially [1]. However, in the classroom, teachers have always found the lack of ability of learners in critical thinking so that classes tend to be passive [2]. Attitude and tendencies associated with critical thinking can generate by applying cooperative learning model STAD. There are two attitudes and trends among the other is respect for the opinions of others and tolerance for uncertainty. So that in the process of teaching and learning activities of teachers not only give attention to the interaction between him and the student but the student interaction with other students [3]. STAD as one of the techniques of cooperative learning, which is considered a conventional technique. Because, STAD cooperative learning model can improve critical thinking skills [4].

Critical thinking skills are not innate but come as practiced or implemented through a process of learning by educators as facilitators in the learning. So should the effort of teachers to create and understand the innovations in a learning process. These innovations would be able to grow and improve students' critical thinking skills [5]. The teaching of thinking often becomes an integral part of the teaching routine should be done with just a small extra effort [3]. Limitations of student learning time in the classroom is still one obstacle, so it needs a bit of extra effort Edmodo to continue the learning at home. Edmodo is often called Facebook for education. Unique social media community designed for teaching [6]. Edmodo, including mobile and web-based learning using an application that has provided, in which teachers, students, and parents can interact [7]. Learning to use Edmodo had a positive response from students [8].

In Indonesia, Nearly $80 \%$ of adolescents aged 10-19 in 11 provinces in Indonesia addicted to using social media. Most teens are still less wise in using social media, $24 \%$ of users admitted to using social media to interact with people who are not recognized, $14 \%$ of users accessing pornographic content, and the remainder for online gaming and other interests [9]. Now, based learning online can be affordable, coupled with the availability of internet signal that allows a person to access the websites of learning. So that the development of internet-based learning is needed, and the use of mobile technology is very carefully related to the lives of children and parents. Hence, its use for educational purposes is a necessity [10]. 


\section{Theory}

Learning is an enduring change in behavior, or the capacity to behave in a certain way, resulting from practice or other forms of experience [11]. Learning is a mental/psychological activity that interacts directly actively with the environment that results in changes in knowledge, skills, and attitudes [12]. Gagne defines learning as an event that is carefully motivated by the aim that knowledge gained through the learning process can be useful [13]. Physics learning is often associated with events or phenomena observed in daily life, explaining events in a simple way [14]. Learning physics is a process that ideally focused activities on encouraging students to think critically and develop arguments using evidence, justification, and practical explanation [15]. Based theories can conclude that the teaching and learning of physics is a process of interaction of teachers and students in a learning environment where teachers help students to learn about the phenomenon observed in everyday life, which allows students to think critically and argue using evidence.

According to Gross, STAD as one of the techniques of cooperative learning, is considered a proper technique. Because STAD can improve student motivation to learn by exchanging and sharing information, mutually reinforcing, give feedback, and have a responsibility to do their work in a group. It was stated that STAD has five main components, namely presentation classes, team studies, quizzes, individual improvement scores, and team recognition [16].

Edmodo is a social network designed for the unique learning community. People have called Facebook for education [6]. Edmodo is web-based learning developed based on the development of Web 2.0 and mobileassisted learning. Edmodo includes web-based and mobile learning using applications that have provided, where teachers, students, and parents can interact [7]. Edmodo is a social networking and micro-blogging service that is designed specifically for education, which can operate like any other social media such as Twitter. By checking the access road to a particular room or a group, teachers and students can exchange notes, links, files, announcements, tasks, and exchange information in a secure environment [17].

With many advantages offered by Edmodo; Teachers, students, and parents can see why social networking is growing so fast education. The advantages of Edmodo are as follows [17]: (a) Easy to send files, images, videos, and links; (b) Send individual messages to teachers; (c) Create groups for individual discussion according to specific classes or topics; (d) A safe environment for new students; (e) Messages are designed to be easier to understand and are not limited by the number of characters. Furthermore, from the advantages that have offered, Edmodo also has its disadvantages. Disadvantages of Edmodo is as follows [17]: (a) disturbances in internet connection may affect the website run slower; (b) Students have limited access to an exit because it is only limited in the class; (c) Still in the development version and not wholly perfect.
Thinking is a well-organized mental process and works a role in the decision-making process to solve problems by analysing and interpreting data in scientific inquiry activities [2]. Can obtain a design that critical thinking is the thinking skills must be developed and trained from an early time by students to address and provide solutions to social problems that occur both in the community of the students as well as in comprehensive and reliable [18]. According to Ennis, critical thinking is thinking in the form of thought-out revisiting something that has happened to focus on what is believed and done if faced with a problem [19]. According to Ennis, critical thinking skills indicators consist of five types, namely: a) elementary clarification; b) basic support; c) inferring; d) advanced clarification; e) create strategies and tactics.

\section{Method}

This study uses one group pretest-posttest design shown in Table 1. The population of this research is class VIII MTs At-Taqwa Beru Sikka. The sampling technique used random cluster sampling divides the two classes of Experimental Class (EC) and Control Class (CC). The experimental class is in class VIII-C, and the control class is in class VIII-D.

Table 1. Research Design

\begin{tabular}{clccc}
\hline No & Class & Pre-test & Treatment & Post-test \\
\hline 1 & Experiment & $\mathrm{O}_{1}$ & $\mathrm{X}$ & $\mathrm{O}_{2}$ \\
2 & Control & $\mathrm{O}_{3}$ & $\mathrm{Y}$ & $\mathrm{O}_{4}$ \\
\hline
\end{tabular}

In this study, the aspects studied were the students' critical thinking skills. Thus, the data collection techniques use of test results of the students' critical thinking skills. The matter would be given before and after a given treatment. Indicators on aspects of critical thinking skills include elementary clarification, essential support, inferring, advanced clarification, strategies, and tactics.

Test questions that have passed validity and reliability will be given to the experimental class and the control class for evaluation. The research instruments were adjusted accordingly with the adopted critical thinking indicators. The following lattice of test instruments for critical thinking skills can be seen in Table 2.

In this study, the experimental class using cooperative learning model type STAD with Edmodo assisted to continue the learning at home, so that every student directed to have Edmodo accounts. After having an account, each student was given a coding class to join the class created by the researcher. Edmodo learning media used to support cooperative learning model type STAD as a medium that connects teachers and students and students with students in hopes of facilitating information exchange activities after school hours at the end of class. Before learning implemented in the classroom. Edmodo's role in this research is to upload the 
required learning device. The device consists of a teaching topic, student worksheets, and quizzes.

Table 2. Grating test instruments critical thinking skills

\begin{tabular}{|c|c|c|c|}
\hline No & $\begin{array}{c}\text { Indicator of } \\
\text { critical thinking }\end{array}$ & $\begin{array}{l}\text { Critical thinking } \\
\text { sub-indicators }\end{array}$ & $\begin{array}{l}\text { Distribution } \\
\text { of questions }\end{array}$ \\
\hline 1 & $\begin{array}{l}\text { Provide a Simple } \\
\text { explanation }\end{array}$ & $\begin{array}{l}\text { Answering the } \\
\text { question "why" } \\
\text { and "how" }\end{array}$ & $1,2,3,4,5$ \\
\hline 2 & Build basic skills & $\begin{array}{l}\text { Consider the use } \\
\text { of appropriate } \\
\text { procedures for a } \\
\text { problem }\end{array}$ & $1,2,3,4,5,6$ \\
\hline 3 & Conclude & $\begin{array}{l}\text { Make conclusions } \\
\text { based on facts }\end{array}$ & $1,2,3,4,5,6$ \\
\hline 4 & $\begin{array}{l}\text { Set strategy and } \\
\text { tactics }\end{array}$ & $\begin{array}{ll}\text { Use } & \text { logic } \\
\text { strategies } & \end{array}$ & $4,5,6$ \\
\hline
\end{tabular}

Analysis of the data used is using a normality test, homogeneity test, independent sample t-test, and test ngain. The normality test used to determine the distribution of the data obtained through critical thinking skills tests normal distribution or not. Homogeneity test used to determine the data gained through critical thinking ability tests between the experimental class and control class homogeneous or not. Tests using independent t-test conducted to know the effect of the carrying out of a sample different from the experimental and control class. The $\mathrm{N}$-gain test was conducted to find out the value of the increase in students' critical thinking skills.

\section{Results and Discussion}

This research was conducted method of one group pretest-posttest design that consisted of two classes. Experimental class (EC) using cooperative learning model STAD assisted Edmodo and Control Class (CC) using cooperative learning model STAD without assisted Edmodo. This research consists of several stages, namely the planning stage, the pre-test, the treatment using the cooperative learning model type STAD modified and without Edmodo-assisted learning, and the final stage of post-test administration. Edmodo is a tool to maintain learning at home can be seen in Figure 1.

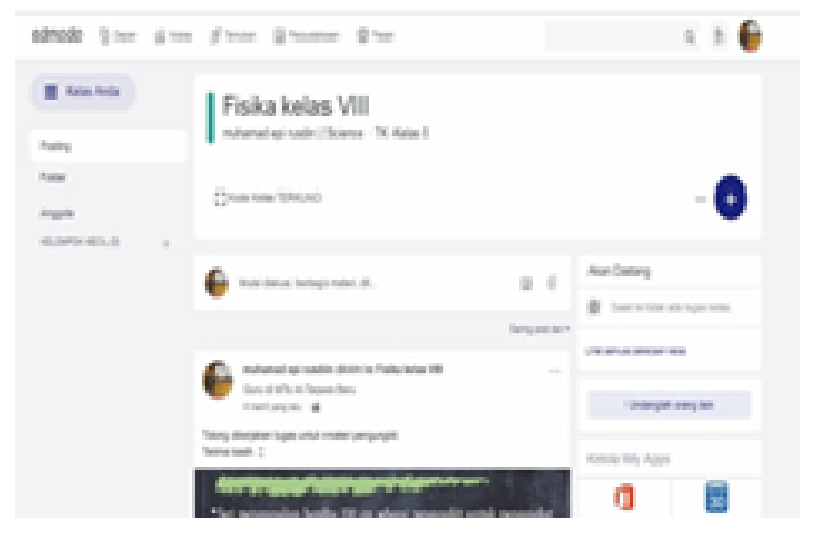

Figure 1. Display of Edmodo class
Furthermore, learning tools in conducting this research need to be validated. Learning device has been validated with four validators, which consists of two lecture of physics education and physics teacher:

1. Validation of design a lesson plan is categorized as very strong at $93 \%$, so it can be said that the design is a perfect lesson plan for use in the learning process.

2. The results of the topic validation categorized as active, with a percentage of $88 \%$, so it can be said that this material is very feasible to be used in the learning process.

3. The results of the validation of test critical thinking skills are categorized as very strong, with a percentage of $79 \%$, so it can be said that this test item eligible for use in research.

The hypothesis usually considered as a principal instrument in the study. Its principal function is to suggest new experiments and observations. Many experiments carried out with intentional hypothesis testing objects. The following is a description of some tests to find a hypothesis.

\section{Normality test}

Normality testing is done by Chi-Square test

Table 3. Grating test instruments critical thinking skills

\begin{tabular}{lclcc}
\hline No & Class & & Pre-test & Post-test \\
\hline 1 & Experiment & Minimum & 61.32 & 54 \\
& & Maximum & 61.90 & 85 \\
& & average & 14.16 & 72.68 \\
& & observer & 32.69 & 16 \\
& & $X^{2}$ count & 79.45 & 4.93 \\
& \multirow{4}{*}{ Control } & $X^{2}$ table & 46.76 & 9.49 \\
& Minimum & 41.47 & 30 \\
& & Maximum & 46.67 & 72 \\
& & average & 18.25 & 57.17 \\
& & observer & 7.14 & 23 \\
& & $X^{2}{ }_{\text {count }}$ & 65.91 & 0.83 \\
& $X_{\text {table }}^{2}$ & 58.77 & 9.49 \\
\hline
\end{tabular}

The results of the analysis of the experimental class following Table 3. The pre-test and post-test experimental class consisted of 16 students in the experimental class. The average pre-test results of students' critical thinking skills in the experimental class was 27.31 , with a minimum value of 4 and a maximum value of 48. While the average pre-test results of students' critical thinking skills in the experimental class was 27.31 , with a minimum value of 4 and a maximum value of 48. The average post-test results of the students' critical thinking skills in the experimental class is 72.68 , with a minimum value of 54 and a maximum value of 85 .

From Table 2, after calculating the experimental class pre-test data of 6.02 . If consulted with the chisquare table at the significance level of $\alpha=0.05$ obtainable $X_{\text {table }}^{2}=9.49$. Thus we can say that the data pre-test with normal distribution for the experimental class $X^{2}$ count $(6.02)<X^{2}$ table $(9.48)$. As for the data post-test 
experimental class after calculation $X^{2}$ count obtain of 4.93 with chi-square table at significance level $\alpha=0.05$ was obtained $X_{\text {table }}^{2}=9.48$. Thus it can be said that the experimental class post-test data is normally distributed because $X^{2}$ count $(4,93)<X^{2}$ table $(9.48)$.

The analysis results for the control class according to Table 2. The pre-test and post-test control class consisted of 23 students. The average pre-test results of students' critical thinking skills in the $\mathrm{CC}$ is 26.8 , with a minimum of 3 and a maximum value of 46. Meanwhile, the average post-test results of the students' critical thinking skills in the $\mathrm{CC}$ is 57.17 , including a minimum value of 30 and a maximum value of 72 . From Table 2, after calculating the control class pre-test data, $X^{2}{ }_{\text {count }}$ was obtaining of 0.70 . If consulted with the chi-square table at the level of significance, $\alpha=0.05$ was obtained $X_{\text {table }}^{2}=$ 9,49 . Thus it can be said that the control class pre-test data is normally distributed because $X_{\text {count }}^{2}(0,70)<X^{2}$ table (9.49). As for the data post-test control group after calculation $X^{2}$ vount obtain 0.83 , with a chi-square table at the significance level $\alpha=0.05$ get of $X^{2}$ table $=9.49$. It can be concluded that the data post-test control group with normal distribution because $X_{\text {count }}^{2}=0.83<X^{2}$ table $(9.48)$.

\section{Homogeneity Test}

This test carried out to show two or more groups of sample data come from populations that have homogeneous (equal) variance. Data can be said to be homogeneous if the significance value calculation results $>$ significance value $(0.05)$. The results of the analysis of homogeneous test showed that the significance value is 0.06; the result looks like in Table 4.

Table 4. Homogeneity Test Post-test Experiment and Control Class

\begin{tabular}{cccc}
\hline No & Levene Statistic & df & Sig. \\
\hline 1 & 1.227 & 37 & 0.275 \\
\hline
\end{tabular}

Based on Table 4, it can be seen that the data on the post-test experimental and control classes can be said homogeneity, because of the significant value calculation results $>$ value of significance $(\mathrm{P}$-value) is $0.275>0.05$.

\section{Independent Sample t-Test}

Tests using independent sample t-test was conducted to determine the effect of treatment on different samples of the experimental class and control.

Table 5 shows that the average post-test of the experimental class is 72.31 , while the average post-test of the control class is 57.17. The average results of the two classes showed that the average experimental class was higher than the control class, with a difference of 15.14. While the calculation result obtained $t_{\text {count }}$ of 4.80 prices and the price $t_{\text {tabel }} 2.03$ at $\alpha$ of 0.05 with a degree of freedom of 37 , significance value calculation results obtained a significance value of 0.000026 at a significance level of 0.05 because $t$ is more significant than $t_{\text {table }}(4.80>2.03)$ and a significant value smaller than the level of significance $(0.000026<0.05)$. It can be said there is the influence of the use of cooperative learning model Edmodo aided in improving critical thinking skills the student.

Table 5. Result of Independent Sample t-Test

\begin{tabular}{clcc}
\hline No & & Experiment & Control \\
\hline 1 & Mean & 72.31 & 57.17 \\
2 & Observer & 16 & 23 \\
3 & df & 37 & \\
4 & t-count & 4.80 & \\
5 & P-value (Sig) & 0,000026 & \\
6 & t-Table & 2.03 & \\
\hline
\end{tabular}

\section{N-Gain Test}

Research using Edmodo supported cooperative learning models to show very effective results and the use of cooperative learning model without assisted Edmodo showing ineffective results. General description of the improved critical thinking skills of experimental and control class students can be seen in Table 6 .

Table 6. Percentage of N-Gain score

\begin{tabular}{lclcl}
\hline No & Class & \multicolumn{2}{c}{ Statistics } & Category \\
\hline 1 & Experiment & Mean & 61.32 & Quite \\
& & Median & 61.90 & effective \\
& & Std. Deviation & 14.16 & \\
& & Minimum & 32.69 & \\
& & Maximum & 79.45 & \\
& \multirow{4}{*}{ Control } & Range & 46.76 & \\
& & Mean & 41.47 & Less \\
& Median & 46.67 & effective \\
& & Std. Deviation & 18.25 & \\
& & Minimum & 7.14 & \\
& & Maximum & 65.91 & \\
& & Range & 58.77 & \\
\hline
\end{tabular}

Based on the results of the analysis of the N-Gain test (Table 6) shows that the average value of the percentage of the $\mathrm{N}$-Gain score for the experimental class (using Edmodo-assisted cooperative learning models) is $61.32 \%$ included in the category of quite useful, with NGain score of at least $23 \%$ and a maximum of $79 \%$. As for the control group, results show that the average value of the percentage of N-Gain score amounted to $41.47 \%$ is included in the category of less effective with a minimal and maximal score of $58.33 \%$. This is similar with opinion [20], [21]. Harahap [20] said that there was an increase in critical thinking skills when using the cooperative learning model type STAD. This can be seen through the results of research conducted. After doing the calculations the results of the students' critical thinking skills were obtained from an increase of $70.93 \%$ in the first cycle and $86.04 \%$ in the second cycle [19]. Kustandi [21] said that learning using edmodo media was more effective in improving critical thinking skills than learning without using edmodo, with effective value in 
edmodo classes which was $52 \%$ greater than classes without using edmodo which was $24 \%$ [20].

\section{Conclusions}

Based on the results of research conducted by researchers and the discussion presented it can be concluded that the learning process at MTs At-taqwa Beru Sikka uses cooperative learning models with the help of Edmodo as a tool to continue learning at home on work material, and simple aircraft can improve critical thinking skills the student. Based on the analysis using test N-Gain Edmodo aided cooperative learning models included in the category is quite effective.

Two factors led to the use of cooperative learning model aided Edmodo included in the category is quite effective:

1. Specifications smartphones used by students is not good so that the supporting applications such as PDF, Microsoft Office Word, and other supporting applications cannot be used to support the use of Edmodo.

2. The price of the internet quota is still high for the East Nusa Tenggara region. The price of which is only affordable for capable students, so sometimes some students are late in getting information that teachers have shared on the Edmodo application.

\section{Reference}

[1] T. L. Adi Sucipto, A. Efendi, H. N. Hanif, and C. Budiyanto, "The Influence of Learning Management Technology to Student's Learning Outcome," IJPTE Int. J. Pedagog. Teach. Educ., vol. 1, no. 1, pp. 11-18, Feb. 2017.

[2] R. Alfian, E. Wiyanarti, and M. Iqbal, "Increasing of Critical Thinking Students through Cooperative Learning Model TPS Type (Think-Pair-Share) In Social Studies Learning (Classroom Action Research In Class VIII1/Ibnu Thufail Fitrah Insani II Junior High School)," Int. J. Pedagog. Soc. Stud., vol. 2, no. 2, pp. 46-52, 2017.

[3] P. Eggen and D. Kauchak, Strategi dan Model Pembelajaran: Mengajarkan Konten dan Keterampilan Berpikir, 6th ed. Jakarta: Indeks, 2012.

[4] U. Karuniawati, "Pengembangan Perangkat Pembelajaran Dasar dan Pengukuran Listrik dengan Model Pembelajaran Kooperatif STAD untuk Melatih Keterampilan Berpikir Kritis di SMK Negeri 5 Surabaya," J. Pendidik. Tek. Elektro, vol. 5, no. 2, pp. 609-615, 2015.

[5] S. Nurazizah, P. Sinaga, and A. Jauhari, "Profil Kemampuan Kognitif dan Keterampilan Berpikir Kritis Siswa SMA pada Materi Usaha dan Energi," J. Penelit. Pengemb. Pendidik. Fis., vol. 3, no. 2, pp. 197-202, 2017.
[6] G. Carlson and Raphael, Let's Get Social The Educator's Guide to Edmodo. Arlington: International Society for technology in education, 2015.

[7] H. Bicen, "The Role of Social Learning Networks in Mobile Assisted Language Learning: Edmodo as A Case Study," J. Univers. Comput. Sci., vol. 21, no. 10, pp. 1297-1306, 2015.

[8] D. Sulisworo and K. Permprayoon, "What is the Better Social Media for Mathematics Learning? A Case Study at A Rural School in Yogyakarta, Indonesia," Int. J. Emerg. Math. Educ., vol. 2, no. 1, pp. 39-48, 2018.

[9] A. Hapsari and A. D. Ariana, "Hubungan antara Kesepian dan Kecenderungan Kecanduan Internet pada Remaja," $J$. Psikol. Klin. dan Kesehat. Ment., vol. 4, no. 3, pp. 164 171, 2015.

[10] A. Sahin, N. Top, and E. Delen, “Teachers' First-Year Experience with Chromebook Laptops and Their Attitudes Towards Technology Integration," Technol. Knowledge, Learn., vol. 21, no. 3, pp. 361-378, 2016.

[11] D. H. Schunk, Learning Theories An Educational Perspective. Boston: Allyn \& Bacon, 2012.

[12] W. Winkel, Psikolog Pengajaran. Jakarta: Gramedia, 1989.

[13] R. M. Gagné and K. Medsker, The Conditions of Learning: Training Applications, 5th ed. Pennsylvania: Harcourt Brace College Pub, 1996.

[14] H. Stachowiak, "Modelle: Konstruktion der Wirklichkeit," J. Philpapers, vol. 45, no. 2, pp. 226-226, 1989.

[15] D. Cross, G. Taasoobshirazi, S. Hendricks, and D. T. Hickey, "Argumentation: A Strategy for Improving Achievement and Revealing Scientific Identities," Int. J. Sci. Educ., vol. 30, no. 6, pp. 837-861, 2008.

[16] Y. Q. Yusuf, Y. Natsir, and L. Hanum, "A Teacher's Experience in Teaching with Student Teams-Achievement Division (STAD) Technique," Int. J. Instr., vol. 8, no. 2, pp. 99-112, 2015.

[17] C. Wankel, Educating Educators with Social Media. United Kingdom: Emerald Group Publishing Limited, 2011.

[18] R. S. Putra, "Penerapan Metode Diskusi Tipe Think Pair Share (TPS) untuk Meningkatkan Keterampilan Berpikir Kritis Siswa dalam Pembelajaran IPS," Int. J. Pedagog. Soc. Stud., vol. 1, no. 1, pp. 119-131, 2016.

[19] R. H. Ennis, "Critical Thinking: A Streamlined Conception," Teach. Philos., vol. 14, no. 1, pp. 5-24, 1991.

[20] A. N. Harahap and I. Harahap, "Penerapan Model Pembelajaran Kooperatif Tipe STAD Untuk Meningkatkan Kemampuan Berpikir Kritis Siswa," PeTeKa (Jurnal Penelit. Tindakan Kelas dan Pengemb. Pembelajaran), vol. 2, no. 2, pp. 45-51, 2019.

[21] C. Kustandi, "Efektivitas E-Learning Berbasis Edmondo dan Schoology Terhadap Kemampuan Berfikir Kritis Mahasiwa Program Studi Teknologi Pendidikan FIP UNJ pada Mata Kuliah Profesi Pendidikan," J. Educ., vol. 2, no. 1, pp. 1-9, 2017. 